\title{
Morphometric Analysis of Gubi Dam Basin for Flood Vulnerability Using Shuttle Radar Topographic Mission (STRM)
}

\author{
Garba T. ${ }^{1} \quad$ Gana B. A. ${ }^{1} \quad$ Abdurraheem, M. $^{2}$ \\ 1.Department of Environmental Management Technology, Abubakar Tafawa Balewa University, Bauchi, \\ Nigeria \\ 2.National Center for Remote Sensing Jos, Plateau State, Nigeria
}

\begin{abstract}
This paper examines the relationship between the different morphometric parameters and characters of the drainage terrain. To do that, Gubi dam basin in Bauchi state, Nigeria drainage characteristics was delineated using Shuttle Radar Topographic Mission (SRTM) data. The Aspect, Drainage, and Slope maps were prepared using ArcGIS 10.2.1 software. The Gubi Dam is fifth-order stream that exhibits dendritic to sub-dendritic pattern. The trails drainage patterns are also observed in some areas of the basin, which may be due to the effect of regional tectonics. The mean bifurcation ratio is 1.47 showing normal basin which is somehow controlled by structural disturbances. Drainage density $(0.25)$ shows very coarse drainage texture also having positive correlation with stream frequency. The elongation ratio is 0.08 along with circulatory ratio $(0.21)$ shows elongated nature of the basin. The low values of drainage density and stream frequency imply that surface run-off is not quickly removed from the basin, making it susceptible to flooding and gully have very little effect on the extent to which the surface has been lowered by agents of denudation.
\end{abstract}

Keywords: Morphometric, Flood, Shuttle, Radar, Topographic, Mission

DOI: $10.7176 / \mathrm{JEES} / 10-3-08$

Publication date:March $31^{\text {st }} 2020$

\section{Introduction}

The characteristics of drainage basins depend on the slope, regional tectonics, geology of the catchment area, and aerial climate. The method of quantitative analysis of drainage basins was developed by Horton (1945) and modified by Strahler (1964) to evaluate the nature of the drainage basins, relationship with character of the terrain, for deriving means to safeguard and manage the natural resources and combating natural hazards.

Morphometric analysis is an important aspect of characterization of watersheds. It involves computation of quantitative attributes of the landscape related to linear, aerial and relief aspects from elevation surface and drainage networks within a watershed (Ayele et al, 2017). Morphometric study of a basin delivers information about different features and characterizes the drainage system of basin in features (Strahler $\boldsymbol{e t}$ al., 1964; Dubey $\boldsymbol{e t}$ al., 2015).

Morphometric analysis represents a relatively simple approach to describe the hydro-geological behavior, landform processes, soil physical properties and erosion characteristics and, hence, provides a holistic insight into the hydrologic behavior of watersheds (Strahler, 1964). The hydrological response of watersheds is interrelated with their physiographic characteristics, such as size, shape, slope, drainage density and length of the streams (Gregory and Walling, 1973).

The geographic and geomorphic features of a drainage basin are significant for hydrological research including the assessment of groundwater potential, etc. (Rai et al., 2014). Geology, relief and climate are the main factors of running water systems working at the basin scale (Rastogi and Sharma, 1976). Geographical Information System (GIS) methods are nowadays in usage for evaluating several terrain and morphometric parameters of the drainage basins and watersheds, as it provide a flexible atmosphere and a significant tool for the manipulation and study of spatial information (Hajam et al., 2013).

Drainage basin morphometric information is very important in any undertaking to control incidence of flooding in an area. In this study, basin morphometric parameters using GIS was used to examine the flood potentials of the Gubi basin. This will provide information about floods in the drainage basin. The data on the drainage basin morphometric parameters will enhance the management of flooding in the area.

The aim of the this paper is to evaluate the drainage characteristic of the Gubi dam using remote sensing and GIS and determine its usage in environmental monitoring and management. This study used the morphometric technique to give a vision of the different geo-hydrological features of the drainage basins of the study area to help in the determination of its importance in environmental management and monitoring. The study is also expected to provide base-line information for future research in surface and groundwater hydrology.

\section{Study area}

The source of water in Gubi dam is mainly coming from three tributaries, namely Gubi River, Tagwaye river link with Shadawanka and Ran River. The function of the dam is to supply the state capital and its environs with potable 
water. Constructed in 1979, Gubi dam lies between latitude $10^{\circ} 23{ }^{\prime} 36.3^{\prime \prime} \mathrm{N}-10^{\circ} 26^{\prime} 2.6^{\prime \prime} \mathrm{N}$ and longitude $9^{\circ} 50^{\prime} 11.2^{\prime \prime}$ - 9 $52^{\prime} 41.3$ '. Located in the northern part of Bauchi town, Nigeria, Gubi basin lies between latitude $9^{\circ} 41^{\prime} 50.0^{\prime \prime}$ - 10'48'4.0', and longitude 9'3'33.0' $-10^{\circ} 34^{\prime} 15.1^{\prime}$ '

The region is classified as tropical and the rainfall in the dam basin ranges from $970 \mathrm{~mm}$ to $1400 \mathrm{~mm}$ with about 50 to $60 \%$ of this rainfall occurring between July and August. The dam is used for drinking, irrigation and fishing by settlers around the dam (BASWB, 1981).

\section{Materials and methods}

Basically, morphometric parameters are broadly divided into three categories, i.e., linear aspect, relief aspect, and aerial aspect of the river basin (Mesa, 2006). These parameters include basin area, perimeter, basin length, stream order and stream length, mean stream length, stream length ratio, bifurcation ratio, basin relief, relief ratio, ruggedness number, drainage density, stream frequency, drainage texture, form factor, circulatory ratio, elongation ratio, length of overland flow, and constant channel maintenance.

The extraction of drainage was done from Shuttle Radar Topographic Mission (SRTM) Digital Elevation Show (DEM) $(90 \mathrm{~m})$ information using ArcGIS 10.2.1 software. The generation of depressionless DEM is dependably the preliminary advances for morphometric investigation of a basin. Depressions are information mistakes or result from the averaging associated with relegating rise esteems to cells (pixels) of limited zone. These fake melancholies meddle with the right directing of flow paths amid the watershed examination, particularly in zones of low elevation. The Watershed progression solves this error by first locating and filling the depressions. This DEM is used to compute the flow direction and flow accumulation raster. This facilitates recreation of these two raster delivers the standard flow paths and sub watersheds. The flow chart of detailed methodology is given in Figure 2. The methods used for analysis of the different parameters and their observed values are listed in Table 1.

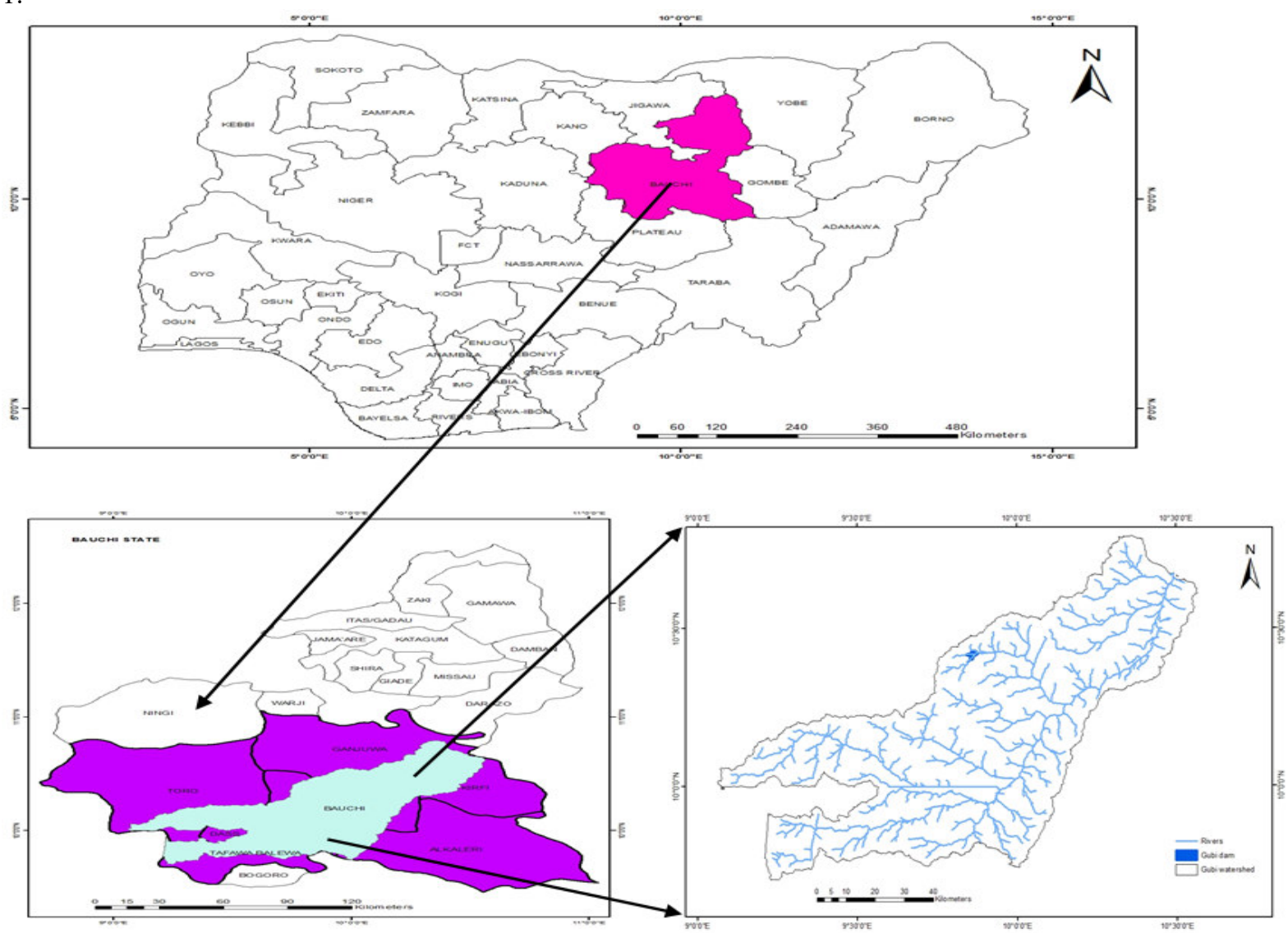

Fig. 1. Gubi drainage basin in Bauchi state, Nigeria

\section{Results and discussions}

\subsection{Aspect, slope and relative relieve of the basin}

The aspect of topography is the direction to which it faces (Magesh, Jitheshlal, Chandrasekar, \& Jini, 2013). The vegetation and precipitation is more or less affected by aspect of the topography. The aspect of the Gubi Dam is shown in Figure 5a. These major slopes reflect the higher moisture content and low evaporation that the other parts of the basin which plays an important role to conserve vegetation, forests, and bio-diversity in the study area. The 
slope of the basin is dependent of rock type of its catchment area having varying resistance (Magesh et al., 2011). The slope elements are highly related to run-off of the water, so that affecting the required time for rain water to enter in the river beds that make up the network of the river basin (Villela \& Mattos, 1975).

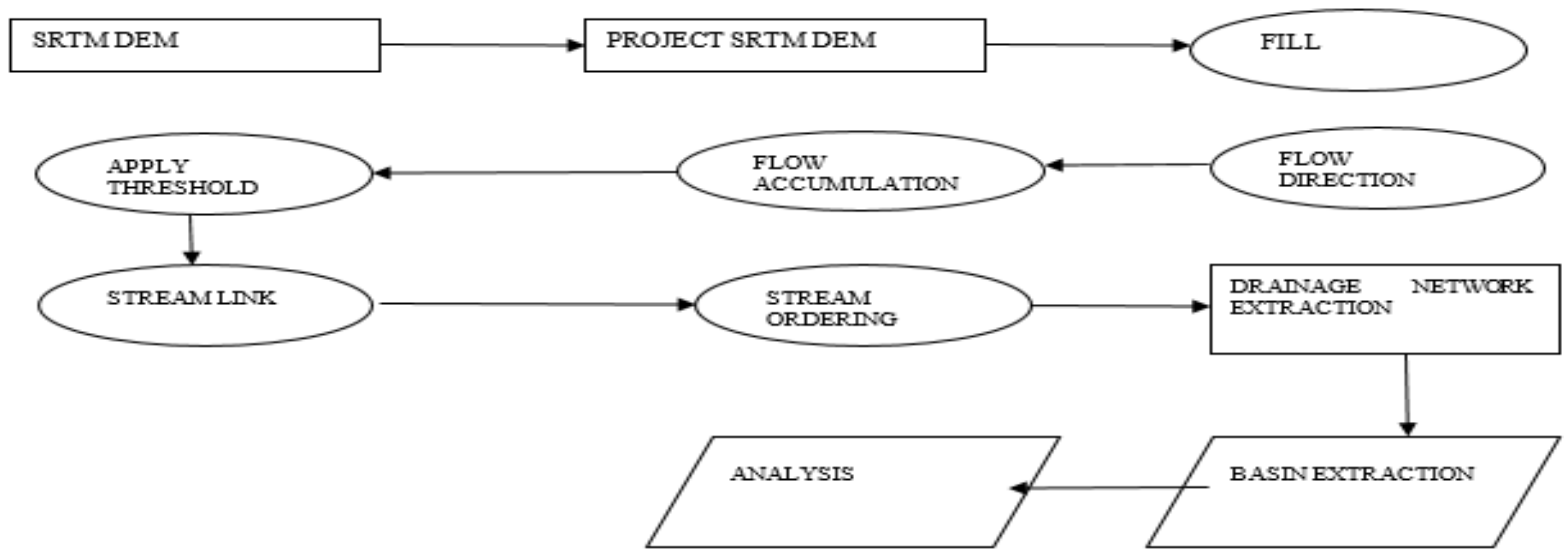

Fig. 2. Flow chart of the methodology

Table 1. Methods of calculations of morphometric parameters and their observed values

\begin{tabular}{|c|c|c|c|}
\hline Morphometric Parameters & \multicolumn{2}{|c|}{ References } & Observed Values \\
\hline Stream Order (U) & Hierarchical order & Strahler, 1964 & $1-5$ \\
\hline Stream Length (Lu) & Length of the stream & Horton, 1945 & $1992 \mathrm{~km}$ \\
\hline \multicolumn{4}{|l|}{ Mean Stream Length } \\
\hline (Lsm) & $\begin{array}{l}\mathrm{Lsm}=\mathrm{Lu} / \mathrm{Nu}, \text { where } \mathrm{Lu}=\text { Stream length of order " } \mathrm{U} " \\
\mathrm{Nu}=\text { Total number of stream segments of order "U" }\end{array}$ & Horton, 1945 & $2.2 \mathrm{~km}$ \\
\hline \multicolumn{4}{|l|}{ Stream Length Ratio } \\
\hline (Rl) & $\begin{array}{l}\mathrm{Rl}=\mathrm{Lu} / \mathrm{Lu}-1 \text {, where } \mathrm{Lu}=\text { total Stream length of order " } \mathrm{U} ; " \\
\mathrm{Lu}-1 \text { = Stream length of next lower order }\end{array}$ & Horton, 1945 & 1.4 \\
\hline \multicolumn{4}{|l|}{ Bifurcation Ratio } \\
\hline$(\mathrm{Rb})$ & $\begin{array}{l}\mathrm{Rb}=\mathrm{Nu} / \mathrm{Nu}+1 \text {, where } \mathrm{Nu}=\text { Total number of stream segments } \\
\text { of order " } \mathrm{U} ; " \mathrm{Nu}+1=\text { Number of stream segments of next } \\
\text { higher order }\end{array}$ & Schumm, 1956 & 1.47 \\
\hline Relief Basin Relief (Bh) & $\begin{array}{l}\text { Vertical distance between the lowest and highest points of } \\
\text { watershed }\end{array}$ & Schumm, 1956 & $240 \mathrm{~m}$ \\
\hline Relief Ratio ( $\mathrm{Rh})$ & $\mathrm{Rh}=\mathrm{Bh} / \mathrm{Lb}$, where $\mathrm{Bh}=$ Basin Relief; $\mathrm{Lb}=$ Basin Length & Schumm, 1956 & $0.35 \mathrm{~m} / \mathrm{km}$ \\
\hline \multicolumn{4}{|l|}{ Ruggedness Number } \\
\hline$(\mathrm{Rn})$ & $\mathrm{Rn}=\mathrm{Bh} \times \mathrm{Dd}$, where $\mathrm{Bh}=$ Basin Relief, $\mathrm{Dd}=$ Drainage density & Schumm, 1956 & 0.06 \\
\hline Drainage Density (Dd) & $\begin{array}{l}\mathrm{Dd}=\mathrm{L} / \mathrm{A} \text {, where } \mathrm{L}=\text { Total length of streams; } \mathrm{A}=\text { Area of } \\
\text { watershed }\end{array}$ & Horton, 1945 & 0.25 \\
\hline Stream Frequency (Fs) & $\begin{array}{l}F s=N / A \text {, where } N=\text { Total number of streams; } A=\text { Area of } \\
\text { watershed }\end{array}$ & Horton, 1945 & 0.11 \\
\hline Drainage Texture $(T)$ & $\mathrm{T}=\mathrm{F} s^{*} \mathrm{Dd}$, where $\mathrm{Fs}=$ Stream frequency; & Horton, 1945 & 0.03 \\
\hline & $\mathrm{Dd}=$ Drainage density & & \\
\hline Form Factor (Rf) & $\mathrm{Rf}=\mathrm{A} /(\mathrm{L} b) 2$, where $\mathrm{A}=$ Area of watershed; $\mathrm{Lb}=$ Basin Length & Horton, 1945 & 0.02 \\
\hline \multicolumn{4}{|l|}{ Circularity Ratio } \\
\hline (Rc) & $\begin{array}{l}\mathrm{Rc}=4 \pi \mathrm{A} / \mathrm{P} 2 \text {, where } \mathrm{A}=\text { Area of watershed; } \mathrm{P}=\text { Perimeter of } \\
\text { watershed; } \pi=3.14\end{array}$ & Miller, 1953 & 0.21 \\
\hline Elongation Ratio $(\mathrm{Re})$ & $\begin{array}{l}\operatorname{Re}=2 \sqrt{ }(A / \pi) / L b \text {, where } A=\text { Area of watershed; } L b=\text { Basin } \\
\text { Length; } \pi=3.14\end{array}$ & Schumm, 1956 & 0.08 \\
\hline \multicolumn{4}{|l|}{ Length of Overland } \\
\hline Flow (Lof) & Lof $=1 / 2 \mathrm{Dd}$, where $\mathrm{Dd}=$ Drainage density & Horton, 1945 & 2.00 \\
\hline \multicolumn{4}{|l|}{ Constant Channel } \\
\hline Maintenance (C) & $\mathrm{C}=1 / \mathrm{Dd}$, where $\mathrm{Dd}=$ Drainage density & Horton, 1945 & 4.00 \\
\hline
\end{tabular}

source: Singh etal 2019 and modified by the authors 
The slope map is very useful to delineate watershed planning, agriculture, deforestation/afforestation, water harvesting, civil engineering purpose, and morpho-conservation practices (Sreedevi et al., 2005). The topographical characteristic of a basin is determined using the relative relief of its catchment area (Gayen, Bhunia, \& Shi, 2013). The Gubi catchment is having highest relief as $240 \mathrm{~m}$ (Figure 4). The low relief designated in the SW side suggests that this area of the basin is flat to gentle slope type (Figure 4). So the SW area is more prone to water accessibility and also suitable for agriculture activities.

\subsection{Linear aspect}

The linear aspects include the stream order $(\mathrm{U})$, stream length $(\mathrm{Lu})$, mean stream length (Lsm), stream length ratio $(\mathrm{RL})$, and bifurcation ratio (Rbm), which are determined and results have been presented in Table 1 .

Stream order (U), stream length (Lu), and mean stream length (Lsm)

The designated stream order $(\mathrm{Nu})$ is the first step in the drainage basin analysis. In this study, ranking of the stream was carried out following Strahler (1964). The catchment have 388 first-order streams, 190 second-order streams, 93 third-order streams, 68 fourth-order streams, and 154 fifth-order streams (Figure 5). The mean stream length of the basin is $2.2 \mathrm{~km}$. In general, there is a decrease in stream frequency as the stream order increases in the present study.

\section{Stream length ratio $(\mathrm{RI})$}

The stream length ratio $(\mathrm{Rl})$ is the resultant of mean stream length of a given order $(\mathrm{Lu})$ to the mean stream length of next higher order $(\mathrm{Lu}+1)$. It is somehow controlled by the slop and regional topography, and thus controls the discharge and erosional activity of the particular watershed or basin (Sreedevi et al., 2004; Thomas et al., 2010). The stream length ratio values are calculated following Horton (1945). The mean values of stream length ratio for the Gubi catchment is 1.4 Increase in the stream length ratio from lower to higher orders successively reveals geomorphic maturity of the basin (Kanhaiya et al., 2018; Rai et al., 2018; Thomas et al., 2010).

\section{Bifurcation ratio $(\mathbf{R b})$}

Bifurcation ratio $(\mathrm{Rb})$ is the ratio between the numbers of stream segments of any given order $(\mathrm{Nu})$ to the number of stream segments of next higher order $(\mathrm{Nu}+1)$. The bifurcation ratio for fifth to fourth order is 0.44 , fourth to third order is 1.37, third to second order is 2.04 and second to first order is 2.04 with a mean value of 1.47 which shows very small structural control and elongated shape of the basin. The medium $\mathrm{Rb}$ ratio of the basin shows the structural and lithological control. The formula, reference, and calculated values are listed in Table 1.

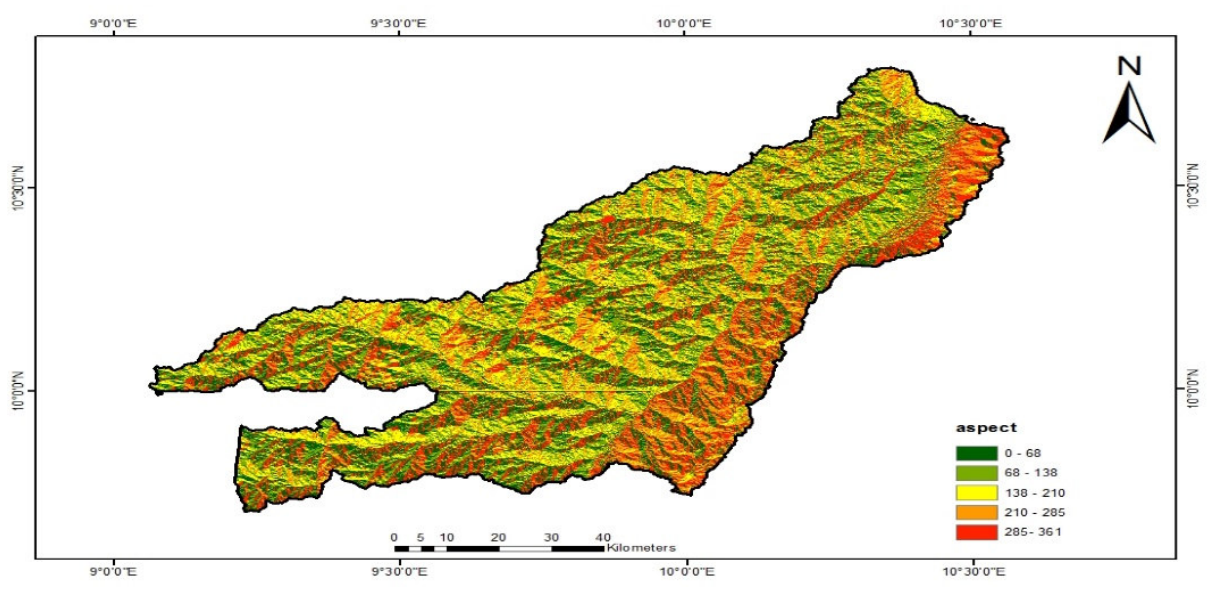

Fig. 2. Aspect map of Gubi basin 


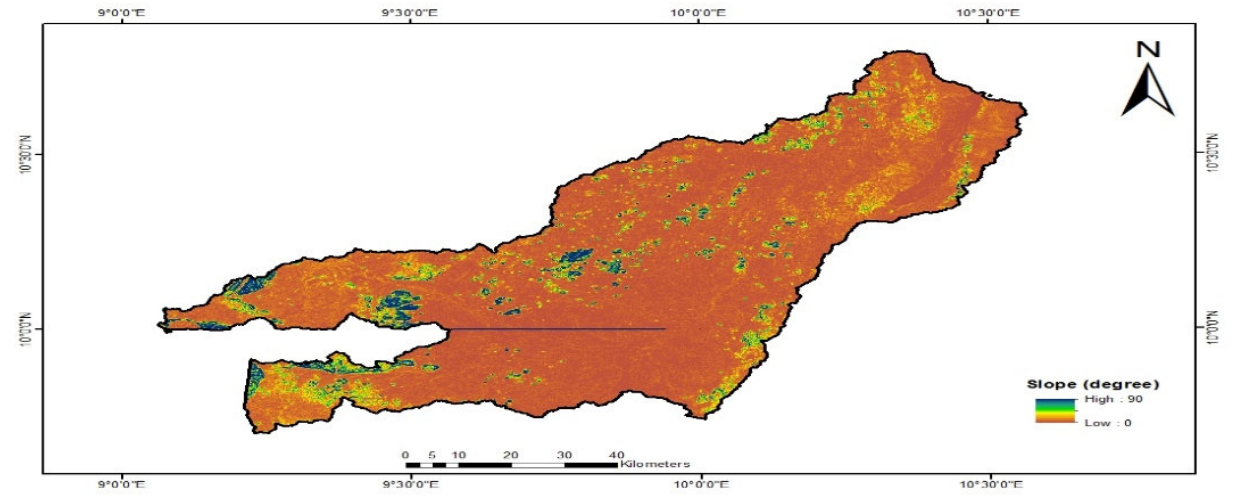

Fig. 3. Slope map of Gubi basin

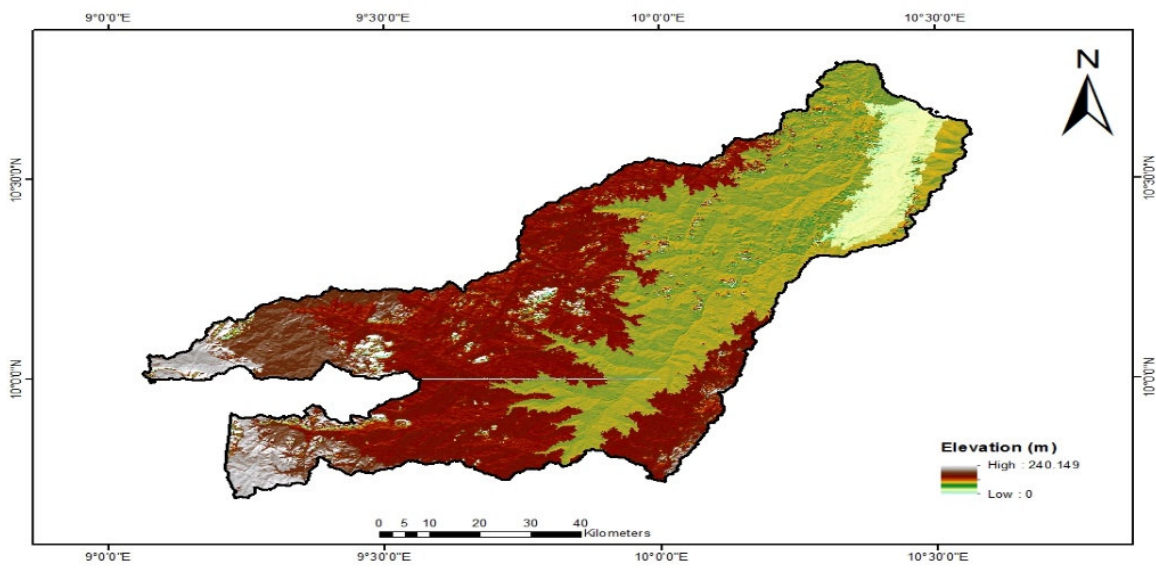

Fig. 4. Elevation map of Gubi basin

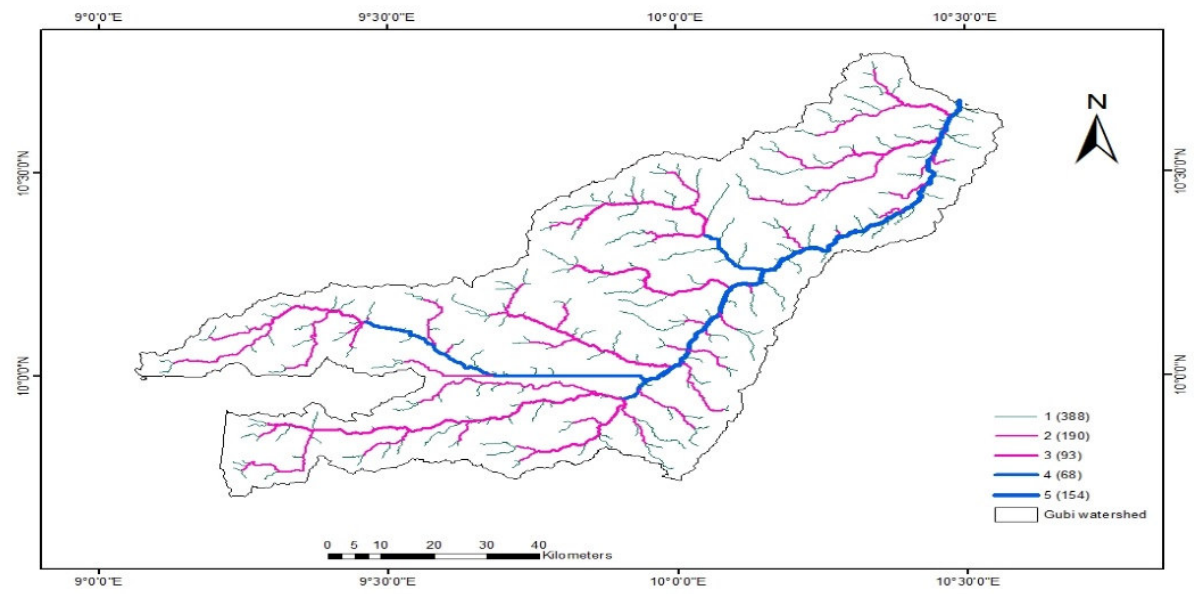

Fig. 5. Different orders of the Gubi basin

\section{Relief aspects}

The relief aspect includes the study of basin relief (Bh), relief ratio (Rh), and Ruggedness number (Rn), respectively. The formulae with references and calculated values are listed in Table 1

\section{Basin relief (Bh)}

The height of the mouth of the catchment is $240 \mathrm{~m}$ from the sea level. The relief of catchment varies in between $240 \mathrm{~m}$ from the height of the catchment mouth. The calculate relief of the Gubi catchment is $240 \mathrm{~m}$ as given in Table 1. The generalized relief map of the basin is given in Figure 4c.

\section{Relief ratio (Rh)}

Relief ratio $(\mathrm{Rh})$ is the response of horizontal distance between two points $(\mathrm{H})$ to the vertical difference between the same two points $(\mathrm{Lb})$. The calculated value of relief ratio for the Gubi catchment is $0.35 \mathrm{~m} / \mathrm{km}$ as in Table 1 . 


\section{Ruggedness number (Rn)}

Strahler (1958) expressed ruggedness number $(\mathrm{Rn})$ as the product of basin relief and drainage density. The Rn reflects the slop and relief variation in the basin. The low value of $\mathrm{Rn}(=0.06)$ implies that the basin area is less prone to soil erosion and having lack of intrinsic structural complexity in association with the basin relief and drainage density (Vijith and Satheesh, 2006; Thomas et al., 2010) (Table 1)

\subsection{Aerial aspect \\ Drainage density (Dn}

Drainage density (Dn) is defined as the length of streams (L) per unit of drainage area (A) and measured by dividing the total length of stream by the area of a drainage basin (Horton, 1945). It reflects the interaction between climate and the geological setup. There is a high correlation among drainage density, precipitation, and evaporation (Horton, 1932). Drainage density describes the spacing of the drainage ways. Higher this number means closer together are the channels. Coarse drainage density occurs in regions of highly permeable subsoil material, under dense vegetative cover, and where relief is low. The low drainage density values $(0.25 \mathrm{~km} / \mathrm{km} 2)$ of the Gubi catchment reveal coarse drainage texture, permeable subsurface/subsoil, and dense vegetation in the study area.

\section{Stream frequency (Fs)}

The ratio between total number of streams $(\mathrm{N})$ and area of a basin $(\mathrm{A})$ is known as stream frequency (Fs) as given by Horton (1945). It is dimensionless and is a measure of texture of the drainage basin in geomorphologic terms (Thomas et al., 2010). The ratio $>3$ shows the very rough texture and high run-off on medium-to-high relief of low permeability (Reddy, 2002). The calculated value of stream frequency (Fs) is $0.11 \mathrm{~km}^{-2}(<3)$ showing smooth texture and low run-off on low-to-medium relief of high permeability. The low value of stream frequency (Fs) indicates permeable subsoil and gentler gradient of the catchment area (Kanhaiya et al., 2018; Rai et al., 2018; Thomas et al., 2010)

\section{Drainage texture $(T)$}

The drainage texture is defined as the total number of stream segments of all order in a basin per perimeter of the basin (Horton, 1945). In general, the drainage texture is a measure of relative channel spacing in a fluvial-dissected terrain, which is greatly influenced by the climate, vegetation, lithology, soil type, relief, and stage of development of a watershed (Smith, 1950). In case of the Gubi Dam, the calculated value of the drainage texture is 0.03 showing all drainage are texturally very coarse in nature.

\section{Form factor (Rf)}

Horton (1945) defined the form factor (Rf) as the ratio between basin area (A) and the square of basin length $\left(\mathrm{Lb}^{2}\right)$. Using this method, the calculated value for the study area is 0.02 which confirms flatter peak flow for longer duration in moderately elongated shape. Low form factor ratio indicates basins of flatter peak flow for longer duration (Biswas, 1999) with less side flow for shorter duration and main flow for longer duration (Reddy et al., 2002; Reddy, Maji, \& Gajbhiye, 2004), and vice versa for high ratio.

\section{Circulation ratio $(\mathbf{R c})$}

It is the ratio of area of basin (A) to the area of the circle having the same perimeter of the same basin (Miller, 1953). Similar to form factor, value nearer to one means more circular shape (Strahler, 1964). Runoff in circular shape basins gets more time to stay. Therefore, circular-to-elongate basin is inversely related to their character of movement (rapid or slow) of run-off to outlet and infiltration. These are further subjected to lithology, slope, and land cover of the basins or sub catchments. The calculated value of the circulatory ratio is 0.21 , which indicates elongated shape of the studied river basin.

\section{Elongation ratio (Re)}

According to Schumn (1956), the ratio between diameter of the circle having same area as of the basin and the length of the same basin is defined as elongation ratio $(\mathrm{Re})$ of a river basin. The higher value of the Re indicates high infiltration capacity and low run-off conditions and vice versa (Reddy et al., 2002, 2004). The observed value of the elongation ratio for the Gubi Dam is 0.08 which indicates high run-off and elongated shape of the basin.

\section{Length of overland flow (Lof)}

As per Horton (1945), the length of overland flow (Lof) is the length of water over the ground before it gets concentrated into definite stream channels which affect both the hydrological and physiographic characteristics of the basin. In the present studied basin, the Lof value is 2.0 showing relatively mature stage of the drainage development.

\section{Constant of channel maintenance $(C)$}

It is the inverse of drainage density and expressed with dimension of square per unit (Horton, 1945). It is also defined as the area of the basin needed to develop and sustain a unit length of stream channel (Schumm, 1956). Permeability, rock type, relief, vegetation, and duration of rainfall are the affecting factors of the constant of channel maintenance $(C)$. The high value $(=4.0)$ of constant of channel maintenance for the studied river basin indicates high permeability of subsoil, gentle-to-moderate slope, and high surface run-off. 


\section{Conclusion}

Based on detailed investigation of the Gubi catchment using remote sensing and GIS, and field survey, the following conclusions are made:

The Gubi Dam is fifth-order basing, elongated in nature having basin area $7,922.4 \mathrm{~km}^{2}$, and maximum length of the basin is $691 \mathrm{~km}$. The basin have low drainage density and coarse drainage texture suggests permeable subsurface/subsoil, dense vegetation cover in the study area. The low value of stream frequency indicates permeable subsoil and gradual slope of the catchment area, while the form factor value confirms flatter peak flow for longer duration in moderately elongated shape of the basin. The high value of constant of channel maintenance of the basin indicates high permeability of subsoil, gentle-to-moderate slope, and high surface run-off showing relatively mature stage of the drainage development confirmed by length of overland flow

\section{References}

Ayele, A., Hiroshi, Y., Katsuyuki, S., \& Nigussie, H. A. (2017). "Quantitative Analysis and Implications of Drainage Morphometry of The Agula Watershed in the Semi-arid Northern Ethiopia”. Applied Water Science, 7 (7), 3825-3840.

Biswas, S., \& Sudhakar, S. a. (1999). "Prioritisation of subwatersheds based on morphometric analysis of drainage basin - A remote sensing and GIS approach". Journal of Indian Society of Remote Sensing , 27, 155-166.

BSWB. (1981). "Progress report for the period of 1979-1981". Bauchi: Bauchi state water board.

Gayen, S., \& Bhunia, G. a. (2013). "Morphometric analysis of Kangshabati-Darkeswar interfluves area in West Bengal, India using ASTER DEM and GIS techniques". Geology and Geoscience, 2 (4), 1-10.

Gregory, K. A. (1973). "Drainage Baisn Form and Process: A Geomorphological Approach. Michigan: Wiley".

Hajam, R., \& Hamid, A. A. (2013). "Application of Morphometric Analysis for Geo Hydrological Studies Using Geo-spatial Technology - A case study of Vishar Drainage Basin”. Hydro Current Resources , 4, 157.

Horton, R. (1932). "Drainage Basin Characteristics". Trans Am Geophysics Union, 13,350-361.

Hortn, R. (1945). "Erosion Development of Streams and their Drainage Basins:Hydrophysical approach to Quantitative Morphology". Geological Society of America , 56 (3), 275-370.

Magesh, N., \& Chandrasekar, N. A. (2011). "Morphometric Evaluation of Panasam and Manimuthar Watershed, Part of Western Ghats, Tirunelueli District, Tamil Nadu, India:A GIS Approach". Environmental Earth Sciences , 64, 374-381.

Miller, V. (1953). "A Quantitative Geomorphic Study of Drainage Basin Characteristics in the Clinch Mountain Area, Virginia and Tennes Project". New York: ColumbiaUniversity.

Kanhaiya, S., Singh, B., Singh, S., \& Mittal, P. a. (2018). "Morphometric analysis, bed-load sediments and weathering intensity in the Khurar River basin, Central India". Geological Journal , 1-16.

Magesh, N., Jitheshlal, K., \& Chandrasekar, N. a. (2013). "Geographic Information System-based morphometric analysis of Bharathapuzha river basin, Kerala, India". Applied Water Science , 3, 467-477.

Mesa, L. (2006). "Morphometric analysis of subtropical arid basin (Tuncaman, Argentina)". Environmental Geology, 50, 1235-1242.

Rai, P., Mohan, K., Mishra, S., \& Ahmad, A. A. (2014). “A GIS-based Approach in Drainage Morphometric Analysis of Kanhar River Basin, India". Applied Water Sciences , 14-18.

Rai, P., Chandel, R., \& Mishra, V. a. (2018). "Hydrological inferences through morphometric analysis of lower Kosi river basin of India for water resources management based on remote sensing data". Applied Water Science, 1-15.

Rastogi, R. a. (1976). "Quantitative analysis of drainage basin characteristics". Journal of Soil and water Conservation in India , 26, 18-25.

Reddy, G., \& Maji, A. a. (2004). "Drainage morphometry and its influence on landforms charactersitics in basaltic terrain, Central India: A remote sensing and GIS approach". International Journal of Applied Earth Observation and Geoinfromatiion, 6, 1-16.

Reddy, G., \& Maji, A. a. (2002). "GIS for morphometric analysis of drainage basins". GIS India , 11 (4), 9-14.

Schumm, S. (1956). "Evolution of Drainage Systems and Slopes in Badlands at Perth Ambay, New Jersy". Geological Society of America Bulletin, 67, 597-646.

Singh, S; Kanhaiya, S; Anikta, S and Chaubey, K. (2019). "Drainage network characteristics of the Ghaghghar River Basin (GRB), Son Valley, India". Journal of GEOLOGY, ECOLOGY, AND LANDSCAPES , 3 (3), $159-167$.

Smith, K. (1950). "Standards for grading texture of erotional topography". American Journal of Science , 248 , 655-668.

Sreedevi, P., \& Subrahmanyam, K. a. (2005). "Integrated approach for delienating potential zones to explore for groundwater in the Pegeru River basin, Kuddapah District, Andhra Pradesh, India”. Hydrogeology Journal , 13, 534-545.

Sreedevi, P., \& Subrahmanyam, K. a. (2004). "The significance of morphometry analysis for obtaining 
groundwater potential zones in a structurally controlled terrain”. Environmental Geology, 47, 417-420.

Strahler, A. (1964). "Quantitative Geomorphology of Drainage Basin and Channel Networks". (V. Chow, Ed.) New York: McGraw Hill.

Strahler, A. (1957). “Dynamic Basis Geomorphology”. Geological Society of America , 63 (1), 913-920.

Thomas, J., \& Joseph, S. a. (2010). "Morphometric aspects of the small tropical mountain river system, the southern western Ghats, India". International Journal of Digital Earth , 3 (2), 135-156.

Vijith, H. a. (2006). "GIS based morphometric analysis of two upland sub-watersheds of meenachil river in Kerala". Journal of the Indian Society of Remote Sensing , 34 (2), 181-185.

Villela, S. a. (1975). "Hidrologia aplicada". Sao Paulo: McGrah-Hill. 